\title{
SSRC ANXIETIES OF DEMOCRACY
}

At a fraught moment for democracies worldwide, this series brings together renowned scholars to probe the sources of current apprehensions about democracy and explore how democratic regimes might thrive.

Series Editors: John A. Ferejohn, NYU, Ira Katznelson, Columbia University, and Deborah J. Yashar Princeton University

LATEST TITLES INTHE SERIES:
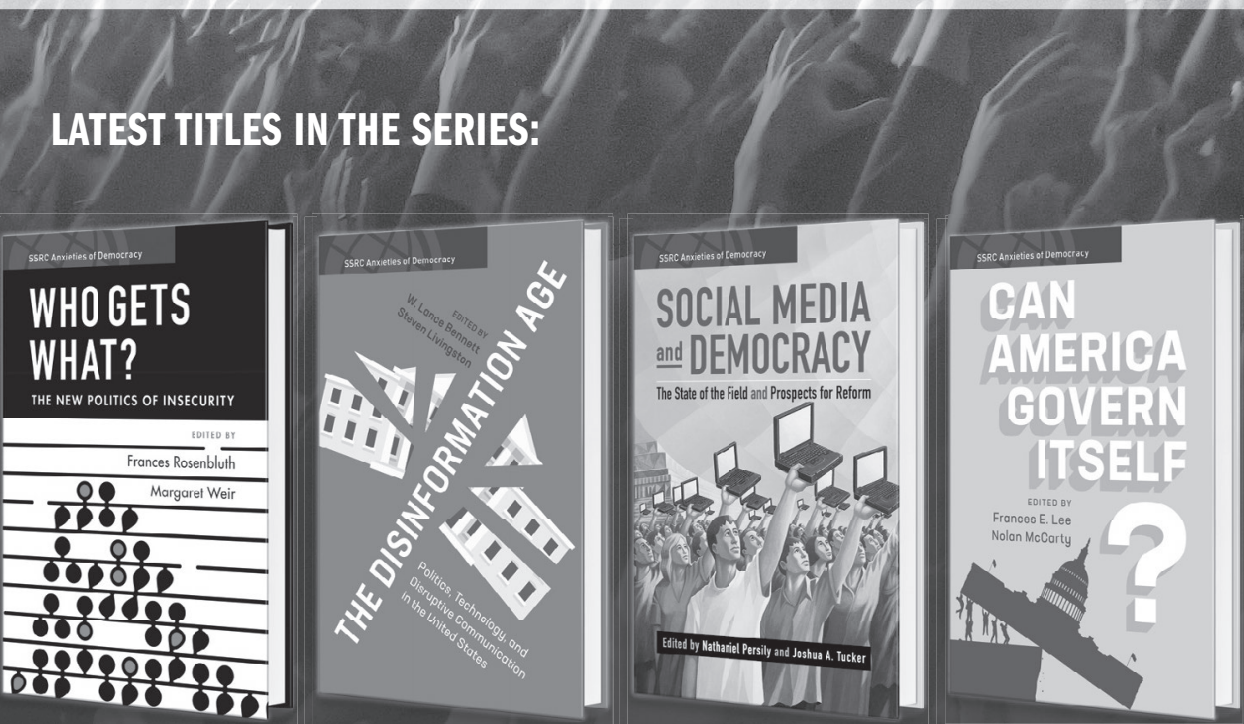

FOLLOW US ON SOCIAL MEDIA

f CambridgeUniversityPressPolitics

(? CUP_Polisci (0) cupacademic

cambridge.org 


\section{THE LATEST TITLES ON U.S. STATE POLITICS FROM CAMBRIDGE}
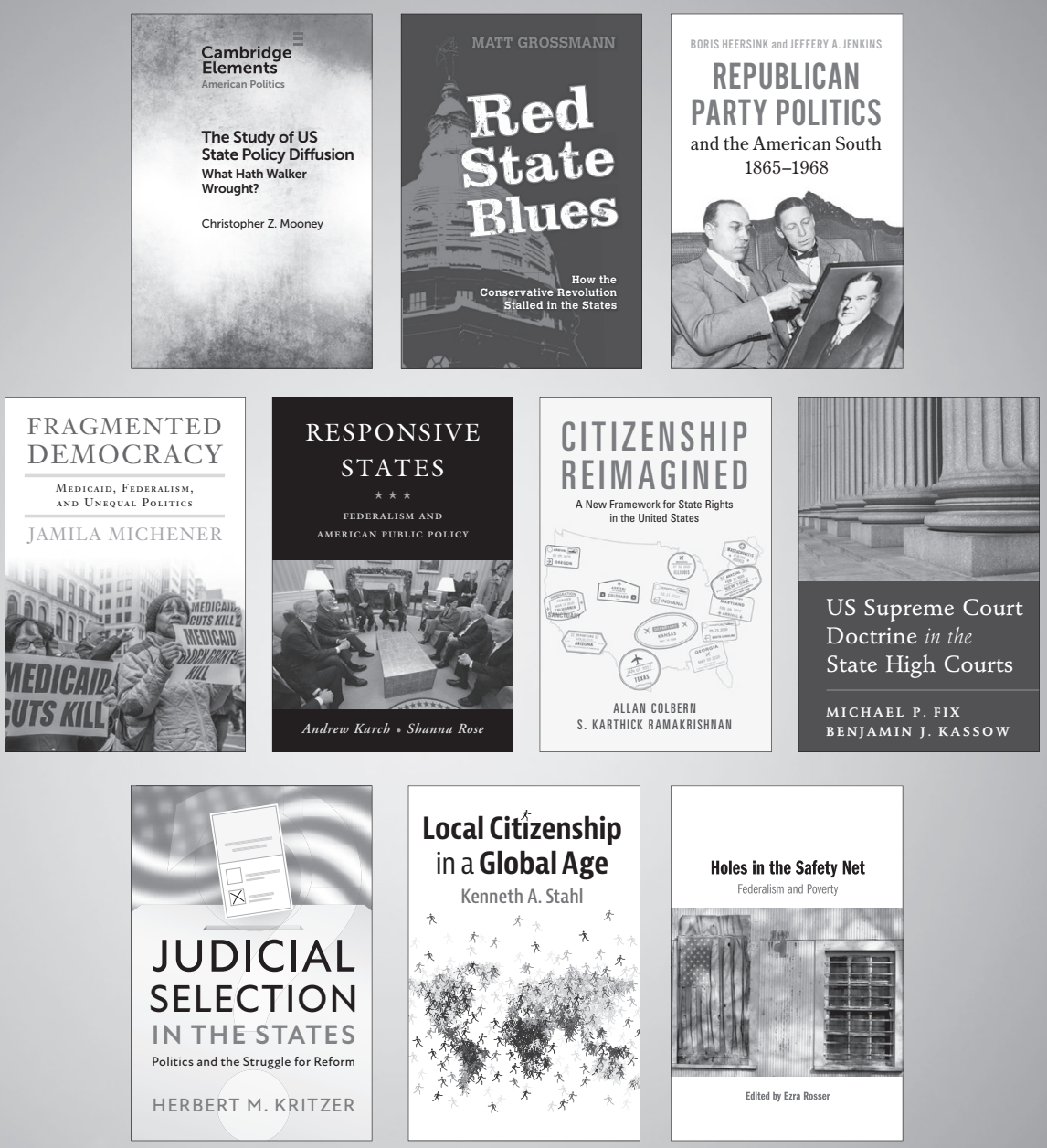

Visit cambridge.org/Politics for more info on these titles and others
CAMBRIDGE UNIVERSITY PRESS 

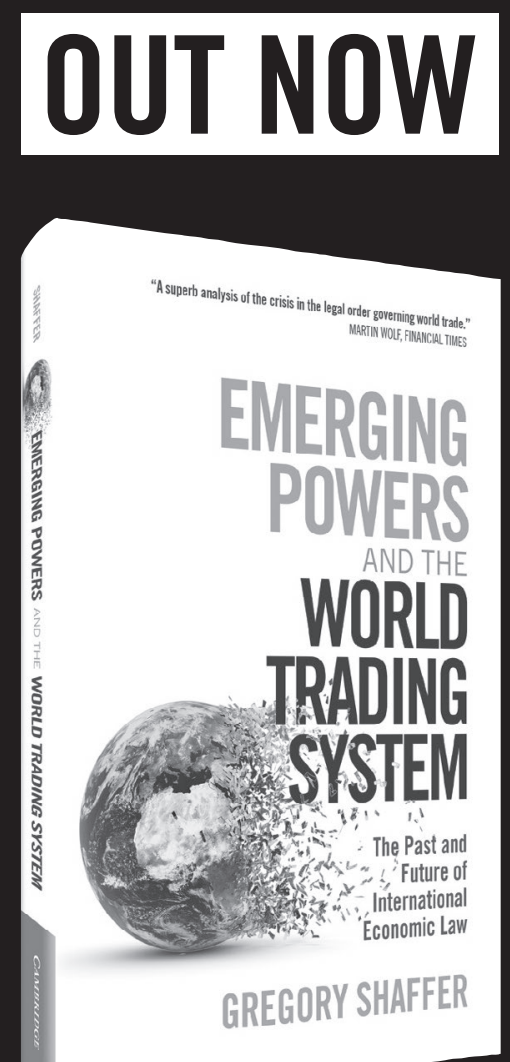

\section{Visit}

\section{GAMBRIDGE.ORG/} EMERGINGPOWERS FOR MORE INFO

Follow us on social media
f CambridgeUniversityPressLaw
( ) CUP_Law
() cupacademic

\section{THE LATEST FROM GREGORY SHAFFER}

Victorious after World War II and the Cold War, the United States and its allies largely wrote the rules for international trade and investment. Yet, by 2020, it was the United States that became the great disrupter - disenchanted with the rules' constraints. Paradoxically, China, India, Brazil, and other emerging economies became stakeholders in and, at times, defenders of economic globalization and the rules regulating it. Emerging Powers and the World Trading System explains how this came to be and addresses the micropolitics of trade law - what has been developing under the surface of the business of trade through the practice of law, which has broad macro implications.

"A superb analysis of the crisis in the legal order governing world trade."

MARTIN WOLF, FINANCIAL TIMES

"If you want to understand the past and the future of the transnational legal order for trade, read this book!" JENNIFER HILLMAN, SENIOR FELLOW AT THE COUNCIL ON FOREIGN RELATIONS

"Eloquently illuminates a complex but vital subject - the law's power to shape a more inclusive model of transnational trade."

ROBERTO AZEVÊDO, FORMER DIRECTOR-

GENERAL OF THE WORLD TRADE ORGANIZATION 


\section{Cambridge $\equiv$ Elements}

\section{American Politics}

The Cambridge Elements in American Politics series publishes authoritative contributions on American politics. This series emphasizes works that address big, topical questions within the American political landscape.

Edited by Frances E. Lee
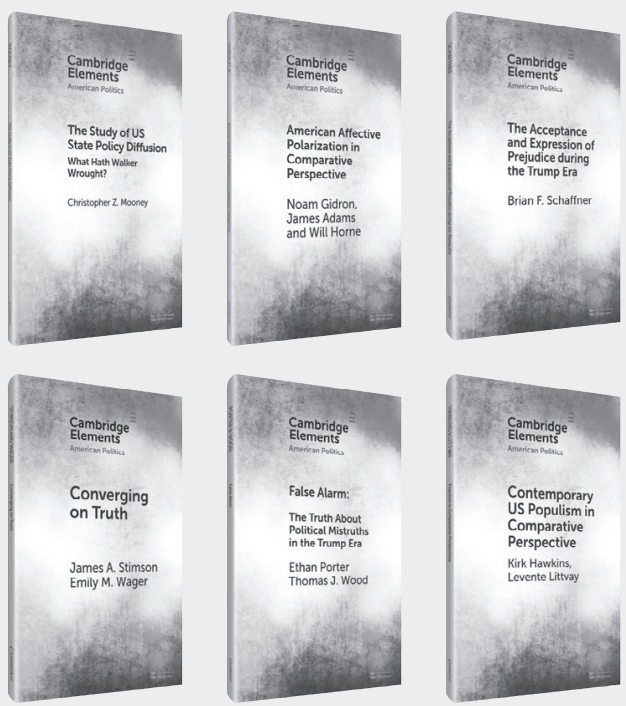

Visit www.cambridge.org/elements for more details on this series and others 


\section{State Politics \& Policy Quarterly}

State Politics \& Policy Quarterly (SPPQ), peer-reviewed and published quarterly, is the premier publication outlet for original research on state politics and policy. The official publication of the State Politics and Policy Section of the American Political Science Association, SPPQ publishes high quality academic studies that develop and test general hypotheses of political behavior and policymaking, exploiting the unique advantages of the states.

\section{Manuscript submission}

All submissions to SPPQ should be made online through ScholarOne at $<$ https://mc.manuscriptcentral. $\mathrm{com} / \mathrm{sppq}>$. For complete instructions and submissions guidelines please visit $<$ cambridge.org/sppq/ifc $>$.

\section{Subscription Information}

State Politics \& Policy Quarterly (ISSN: 1532-4400) is published quarterly, in March, June, September, and December, by Cambridge University Press, One Liberty Plaza, New York, NY 10006, USA.

The subscription price of Volume 21 (2021) including delivery by air where appropriate (but excluding VAT), is $\$ 452.00$ ( $£ 266.00)$ for institutions print and online; $\$ 407.00$ ( $£ 240.00)$ for institutions online only. 2021 subscription rates: Members of the State Politics and Policy Section of APSA receive a hard copy of State Politics \& Policy Quarterly and have free access to the journal online for an annual charge of $\$ 27.00$, or $\$ 10.00$ for students.

Orders, which must be accompanied by payment, may be sent to a bookseller, subscription agent or direct to the publisher: Cambridge University Press, Journals Fulfillment Department, One Liberty Plaza, New York, NY 10006, USA; or Cambridge University Press, University Printing House, Shaftesbury Road, Cambridge CB2 8BS, England. Alternatively, you can place an order online at $<$ cambridge.org/spq $>$.

For single issues, please contact customer_service@cambridge.org.

\section{Advertising}

For information on display ad sizes, rates, and deadlines for copy, please visit the journal homepage at cambridge.org/spq or contact ad_sales@cambridge.org.

ISSN: $1532-4400$

EISSN: $1946-1607$

Copyright $($ American Political Science Association 2021. All rights reserved. No part of this publication may be reproduced, in any form or by any means, electronic, photocopying, or otherwise, without permission in writing from Cambridge University Press. Policies, request forms and contacts are available at: http://www.cambridge.org/about-us/rightspermissions. Permission to copy (for users in the U.S.A.) is available from Copyright Clearance Center http://www.copyright.com, Email: info@copyright.com.

Postmaster: Send address changes to State Politics \& Policy Quarterly, Cambridge University Press, One Liberty Plaza, NewYork, NY 10006, USA. 


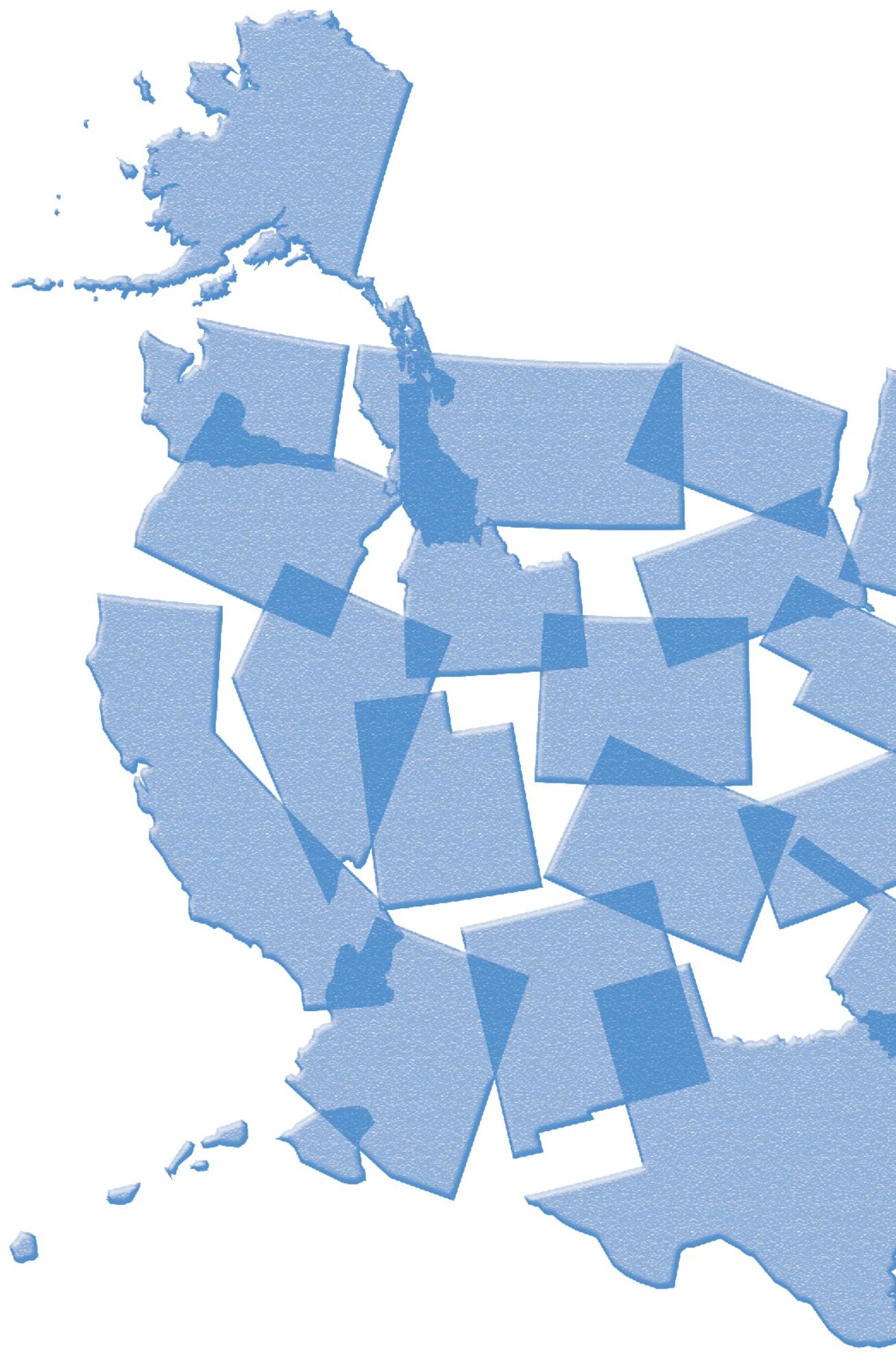

